\section{TEACHING OF GERMAN IN THAILAND: PAST, PRESENT, AND FUTURE}

\section{Wanna Saengaramruang ${ }^{1}$}

\begin{abstract}
This paper aims firstly to give an overview of the development of German language teaching in Thailand at both high-school and university levels from the past up to the present time, since German has been taught in Thailand for more than 80 years and its development has not been studied and documented systematically or continuously. The survey and analysis of German teaching in Thailand in this paper deal with history, teaching approaches, curricula, the development of teaching materials, the number of German language teachers, students, and schools, the attitudes of German language teachers, the expectations of and attitudes towards German teaching among high-school students, and an analysis of the decreasing number of German language teachers and students. Furthermore, this paper also showcases other research works, support organizations, and activities for German language teaching in Thailand.
\end{abstract}

The second purpose of this paper is to point out main problems in the future for the

1 Ph.D., Associate Professor, Faculty of Arts, Chulalongkorn University. The study was funded by the Faculty of Arts, Chulalongkorn University 2005. Thanks to Keeratikhun Chuenchomrat for help in translation. teaching of German in Thailand. The author attempts to state these by means of addressing further questions in the conclusion and epilogue about the interpretation of the Educational Reform Act, the objectives of German language teaching at high-school level, the factors to be taken into account in teaching foreign languages, and, particularly, the policymakers for Thailand's foreign language learning, including the German language.

\section{History}

German language courses were offered for the first time at the Faculty of Arts and Science, ${ }^{2}$ Chulalongkorn University in $1920^{3}$, three years after the founding of the University. The first lecturer in the German Language was Phra Montri Pochanakit ${ }^{4}$ and in 1935, the first native German lecturer, Dr. Klaus Wagner (the first state-university lecturer in the German language), came to the Faculty of Arts. German courses were suspended during World War II and resumed only in 1957 by Dr. Georg Heuser from the DAAD (German Academic Exchange Service). The aim was to establish German language teaching at different levels. ${ }^{5}$ To realize this, the first group

2 This faculty offered the following subjects: languages, literature, and sciences. It is the current Faculty of Arts.

${ }^{3}$ From the report on self-evaluation, Department of Western Languages, Faculty of Arts, Chulalongkorn University, July 2000.

${ }^{4}$ Festschrift (1967: 1). Phra Montri Pochanakit studied Chemistry and Pharmacy many years in Germany before World War I. Later he was a professor at Chulalongkorn University.

${ }^{5}$ The offering of German at the Faculty of Arts was made possible by the cooperation of various 
of ten graduates was sent to the Goethe Institute in Munich, Germany, to learn German. Ampha Otrakul was among them. After one year and a few months, she returned to Thailand in 1959 with the certificate for Teaching German as a Foreign Language and taught at the Faculty of Arts, Chulalongkorn University. Thus, she became the first state lecturer in the German language ${ }^{6}$.

A German language programme was, in fact, offered in 1957, but the first group of students was not from the Faculty of Arts but from the Faculty of Education. By the end of academic year 1962 the first group of three graduates majoring in German was produced. One of them, Chompit Saradatta, was granted a scholarship from DAAD to study in Germany. Then she taught at Chulalongkorn University Demonstration School. At that time, there were only three students in the Department of German Language, Faculty of Arts. 1963 was also the first time that two high-school students majoring in German passed the Entrance Examination to study in the Faculty of Arts. They continued to study German and graduated with a B.A. in 1966. It can be said that the Faculty of Arts was at that time the first institute to produce teachers of German at high-school and university levels ${ }^{7}$. In 1968, Ampha Otrakul graduated from the Ph.D. programme in German

organizations: Faculty of Arts, Dean, the Head of the Department. For German organizations: DAAD, the Goethe Institute, the German Embassy, the German Association for Research (Deutsche Forschungsgemeinschaft, DFG), Inter Nationes, etc. See Festschrift (1967) and 1. Thailändisches Germanistentreffen (2002).

${ }^{6}$ Festschrift, 1967: 22.

${ }^{7}$ Festschrift, 1967: 9, 26.
Language and Literature at the University of Marburg, sponsored by a DAAD scholarship. After that, she was appointed Head of the German Language Department, Faculty of Arts, until her retirement in 1995. Apart from teaching, Ampha Otrakul was a pioneer in a number of German-related fields and has been recognized at the international level. Her most important accomplishments include the translation of German literature and youth literature into Thai, the translation of Thai literature into German ${ }^{8}$, and the production of a Thai-German dictionary. Moreover, she has been the President of the Association of Teachers of German in Thailand for five twoyear terms, from 1993 to 2000 and from 2003 to the present. In the Faculty of Education, Surapee Sunghapichai was recognized for her dedication to the development of the German programme, especially the production of German language teachers at the high-school level. Thanomnuan O'charoen is another key personality in developing the German programmes of the Faculty of Arts. Among other things, she initiated the first M.A. programme in German Language and Literature in 1974, the M.A. programme in Translation and Interpretation (GermanThai $)^{9}$, and the Ph.D. programme in German

\footnotetext{
${ }^{8}$ For example, the translation of Faust by Johann Wolfgang von Goethe, the translation of the works of Böll and those of Nöstlinger; the translation of the German parts of "King Chulalongkorn's Letters from Germany, England and France to Her Royal Highness Princess Nipanopadol on His Visit to Europe in 1907', etc.

9 Thanomnuan O'charoen was also the committee president for the Master's Programme in Translation and Interpretation in 1994. This jointproject included the Department of English, German, French and Japanese. The Master's
} 
language. Wanna Saengaramruang, the first with a Ph.D. in German as a Foreign Language from the University of Kassel 1992, was a pioneer in the writing of German language textbooks, reference works, and handbooks for Thai learners, starting from German Grammar I (for Thai Learners) in 1983, Thai-German Tourism Dictionary ${ }^{10}$ in 1988 and other textbooks and dictionaries for German language learning in Thailand. Moreover, she has been the thesis advisor to graduate students in German as a Foreign Language. Most of them are German language teachers at high-school and university levels. Apart from the graduate-degree programmes in the German language offered by Chulalongkorn University, the M.A. programme in German as a Foreign Language has been offered by Ramkhamhaeng University since 1999.

\section{German language teaching at high- school level}

The first high school to offer German language instruction was Bophitphimuk School in 1934, according to the Announcement of the Ministry of Education. ${ }^{11}$ The teacher was Mr. Reinhold Oswald Geisler. In 1941, a two-year German language course was offered at the then prep school of Chulalongkorn University,

programme in English-Thai Translation and Interpretation was launched in the $2^{\text {nd }}$ semester of 1999 and then followed by the French-Thai programme (O'charoen, 1998: 71-75).

${ }^{10}$ Funded by the Faculty of Arts 1984.

11 Found in the History of Bophitphimuk School, $108^{\text {th }}$ anniversary, p.83, ref. to Taatloha (2002: 195). taught by Dr. Hans Klein, who also taught at the Faculty of Arts, Chulalongkorn University. In addition, other important contributions to German language teaching at the high-school level were made by Srinantha Silapasawat, the former education supervisor of the Ministry of Education, and Prisna Taatloha of the Goethe Institute. Both of them have dedicated themselves to curriculum design, teaching materials, and activities, authoring for example, the series of high-school textbooks Viel Spaß mit Deutsch and organizing Friday seminars (since 1975) ${ }^{12}$ for German teachers. Another personality was Clemens Terörde, Head of the German Language Division and Deputy Director of the Goethe Institute (1990-1998). ${ }^{13}$ With his advice and support, a number of teachers, both at high-school and university levels, were granted scholarships to attend training in Germany. ${ }^{14} \mathrm{He}$ gave also support to the Association of Teachers of German in Thailand in 1993.

12 Taatloha (2002: 202).
${ }^{13}$ Clemens Terörde was recognized as a specialist in Asian and Western cultures with more than 30 years in Asia (1967-1998), for example, Bangladesh, Indonesia, India, and Thailand, 8 years before his retirement. See more information in the article "Vesuch einer Bilanz" in $T D L V$ Forum 6/2001: 109-15 and TDLV-Forum 8/2003: $1-11$.

14 From 1990 to 1997,106 scholarships to Germany were granted to Thai teachers, 18 to Vietnamese teachers, and 9 to teachers from Laos under Mr. Terörde's consideration. Two training scholarships were granted to Thai teachers to attend training courses for teaching German in Indonesia. See more information in TDLV-Forum 2/1997: 86. 
Apart from the Supervisory Unit $^{15}$ in the Department of General Education in the Ministry of Education, there are other Thai and German organizations which have played a key role in supporting German language learning in the form of scholarships and cultural activities. Foremost among them are the Thai-German Society (Thai-Deutsche Gesellschaft) in Bangkok, the German-Thai Society in Bonn (Deutsch-Thailändische Gesellschaft e.V., Bonn), and the ThaiGerman Cultural Foundation (Thai-Deutsche Kulturstiftung). The Thai-German Cultural Foundation has, for instance, granted many Thai-German language teachers scholarships to study in Germany since 1996. Moreover, it has supported other cultural activities financially, for example, the translation of German short stories into Thai on the occasion of HRH Princess Sirindhorn's $48^{\text {th }}$ birthday in $2003 .{ }^{16}$

\section{German language teaching at university level}

In the first few years of the German language programme, the courses available could be divided into two types: those for students from other faculties and those for the students of Arts. Undergraduate curricula, first designed in $1957,{ }^{17}$ had different emphases, as follows:

\footnotetext{
15 The Supervisory Unit was abolished after the merging of the Ministry of University Affairs and the Ministry of Education.

16 Translated by lecturers of the German Section, Faculty of Arts, Chulalongkorn University.

17 This first German programme was offered in the form of a percentage system in 1957 and many revisions were made. The credit system was first used in 1972 (O'charoen, 2000: 18).
}

a. Four-year undergraduate curriculum for students from the Faculty of Arts:

This curriculum was specifically designed for the students of Arts. Emphasis was given to language, literature, and history. It required 7-9 hours a week, and students had to have studied German for two years in high school.

b. 3-4-year undergraduate curriculum for students from the Faculty of Education:

The curriculum required 7-9 hours a week and emphasized language. Introductory courses in literature and history were also offered.

c. Two-year curriculum for students from the Faculty of Sciences:

The courses offered were elective courses requiring 2-3 hours a week.

d. Other courses for lecturers and students from different faculties.

Years later, German language instruction was offered in many high schools and universities, both public and private, at different levels. Apart from English and French, German was offered as major, minor, and elective courses. The curriculum designed by the Faculty of Arts was used as a model, with some modifications made as needed. For example, at Khon Kaen University, ${ }^{18}$ most German courses offered dealt with German for careers because a survey conducted among high-school

\footnotetext{
${ }^{18}$ Weerananthanaphan, 2000: 312.
} 
students in the northeastern region in 1997 showed that the following courses were popular: German for tourism, German for hotel management, and German for business and trade. Thus, the number of literature and linguistics courses were reduced in order to respond to the market. At Ramkhamhaeng University, the emphasis was placed on selfstudy courses; therefore, textbooks were produced for self-study.

\section{Current German language teaching in Thailand}

\section{Teaching approaches and material at high-school level}

One characteristic of German language teaching in Thailand was that the teaching approaches were similar to those adopted in Germany. This was because the same textbooks were used. The methods of German language teaching and the development of textbooks can be divided into three periods as follows:

Phase I (1970-1974): Grammar-translation method: During this period the methodology of grammar-translation was adopted, together with the textbook Deutsche Sprachlehre für Ausländer (Grundstufe in einem Band) written by Schulz and Griesbach. The emphasis was on German grammar and written language more than on spoken language. Teaching techniques were translation and sentence composition. Through these approaches students were trained to think logically and develop grammatical competency. However, they lacked communicative skills. The students trained by this method thought that language was grammar and vice versa.
Phase II (1975-1989): Audio-lingual/audiovisual method: Based on stimulus-response theory (mother-child method), the audiolingual/audio-visual method was adopted during this period, together with the textbooks Deutsch als Fremdsprache $1 A / 1 B$ by Braun, Nieder, and Schmöe. These teaching methods were popular in the 1970s and many forms of audio-visual media were used, for example, tape cassettes, slides, and films. Through the media mentioned, communicative skills were practiced. Conversations in different situations as well as pattern drills in the textbooks contributed to communicative-oriented teaching.

Phase III (since 1989): Communicative Approach: Based on the "Regionallehrwerk"19 (Region-based teaching) approach, the series of textbooks Viel Spaß mit Deutsch 1, 2, 3 was initiated by Thai

\footnotetext{
${ }^{19}$ In the 1980 s, region-based teaching approaches to producting teaching media were much promoted in Germany. This was because, according to a group of academics, textbooks produced under the concept of universality (produced by Germany) were ineffective in different cultures. Thus, regionally-customized textbooks were likely to be more suitable. As a result, German language teachers in each country would rearrange learning topics as appropriate. The objectives and teaching approaches should be learner-oriented, and possible future careers should be taken into account. During the 1980s, region-based teaching was supported by the Goethe Institute in many countries. Textbook series consisted of a learner's book, a workbook, a teaching handbook, a glossary, and tape cassettes. In Asia, a series of textbooks called Lernen Sie Deutsch was produced for use in Korea in 1980 and the textbooks called Kontakte Deutsch, Lehrwerk für Oberschulen in Indonesien for use in Indonesia in 1982 and 1983.
} 
German language teachers. Volume 1 was finished and used in $1989 .{ }^{20}$ The project to write textbooks for Thai students took six years to complete and was financially supported by the Goethe Institute's head office in Munich in cooperation with the Supervisory Unit of the Ministry of Education. It can be said that Viel Spaß mit Deutsch was the first student-oriented German textbook in Thailand because most of the content dealt with what Thai students were interested in. Moreover, Thai culture and traditions were added to train students to disseminate Thai culture to German-speaking tourists. This idea was very innovative and revolutionary at that time.

In 1981 foreign-language teaching at high school level was changed from 2 to 3 years. ${ }^{21}$ At present, German is offered as a major at high school level (Grade 10,11, 12). It is also offered as an elective course for sciences and art-mathematics students in grades $10,11,12$ or students in grades 7-9 in some schools. ${ }^{22}$ Moreover, after the educational reform, the role of the Ministry of Education has been changed to the macro-policy maker and each educational area of the country has been authorized to add local content to the common curriculum formulated by the Ministry. This aims at encouraging the participation of students' parents. Subjects are reclassified into different classes.

\footnotetext{
${ }^{20}$ Saengaramruang, 1992: 40.

${ }^{21}$ Saengaramruang, 1992: 39.

22 Thailand's old educational system is 7-3-2 (7 years of primary school, 3 years of junior high school and 2 years of high school). It has changed to a 6-3-3 system (6 years of primary school, 3 years of junior high school and 3 years of high school).
}

\section{The number of German language Teachers, Students, and Schools}

Divided in different periods, the number of German language teachers, students and schools are as follows:

\begin{tabular}{|l|c|c|c|c|c|}
\hline & $\mathbf{1 9 8 9}^{\mathbf{2 3}}$ & $\mathbf{1 9 9 1}^{\mathbf{2 4}}$ & $\mathbf{2 0 0 1}^{\mathbf{2 5}}$ & $\mathbf{2 0 0 4}$ & $\mathbf{2 0 0 5}^{\mathbf{2 6}}$ \\
\hline $\begin{array}{l}\text { Total } \\
\text { number of } \\
\text { teachers at } \\
\text { high school } \\
\text { level }\end{array}$ & 38 & 38 & $58^{27}$ & 51 & 54 \\
\hline $\begin{array}{l}\text { Total } \\
\text { number of } \\
\text { German } \\
\text { students in } \\
\text { grades 10, } \\
\text { 11 and 12 }\end{array}$ & 1,410 & 2,265 & 3,347 & 2,426 & 3,744 \\
$\begin{array}{l}\text { Total } \\
\text { number of } \\
\text { German } \\
\text { schools }\end{array}$ & 20 & 23 & $41^{28}$ & 38 & 43 \\
\hline
\end{tabular}

\footnotetext{
${ }^{23}$ Saengaramruang, 1992: 39.

${ }^{24}$ Taatloha, 2002: 202-03.

${ }^{25}$ Taatloha, 2002: 203.

${ }^{26}$ Thanks to Prisna Taatloha for the information of 2004-2005

${ }^{27}$ Boonchim (1999: 70) indicated that the number of German language teachers was 53 and that of students was 32 in 1999. The increased number of German language teachers in 1999 to 53 was partly caused by the transformation programme (a programme of training other foreign-language teachers to be German language teachers) initiated by the Goethe Institute.

${ }_{28}$ Among these, 35 schools were under the Department of General Education, 2 under the Minister of University Affairs, and 3 under the office of Private Education. For more information about the school list, see Taatloha (2002: 200-01).
} 
Statistically, the number of teachers, students and schools doubled from 1989 to 2001, but these numbers decreased in 2004. (There were sciences and art-mathematics students that studied German, but the total number of hours per week is less than the number of hours required for German majors).

At present (2005), the number of teachers, schools, and students has increased again. This shows that students are more interested in German, which is a good sign for the German language in the future. ${ }^{29}$ For this reason, quality of teaching should be improved. To do this, clear objectives must be set to determine the direction of teaching and to guarantee the quality. Marketing approaches cannot be the chief consideration in policy making.

\section{Survey of German language teachers at high-school level}

A study by Boonchim (1999) was conducted by means of a questionnaire for 45 highschool German teachers from around the country $(85 \%$ of all German language

\footnotetext{
${ }^{29}$ The increased number of students was probably due to the increasing number of German tourists, people who wanted to continue their studies in Germany because of the availability of the DAAD Information Office in Bangkok and the educational exhibition under the University Marketing project. As a result, more students went to Germany for continuing study because of the lower fees. However, educational subsidies will be cut by the German government. Moreover, more people have been interested in learning German at the Goethe Institute because, perhaps, more Thai women have married Germans.
}

teachers). ${ }^{30}$ The researcher found that only one teacher hadn't been to Germany for any training. The rest had been to Germany for academic purposes at least once. Twenty of them were in Germany for 2-3 months, and ten for $1-4$ years.

Comparing the number above with that of other foreign-language teachers, especially English and French, German language teachers had a better chance to go abroad because of the various forms of support from the Goethe Institute and the DAAD organization, for example, teaching advice and scholarships. $^{31}$

As regards the lack of German language teachers in the past 10 years, the survey showed that low salaries were the main reason (93.3\% of those surveyed). New graduates tended to work for the private sector $(95.6 \%){ }^{32}$ Moreover, new teacher-admission regulations require new teachers to have earned 16 credits of teaching courses. Therefore, job opportunities were limited for those majoring in German from the Faculty of

\footnotetext{
30 Among these 45 teachers, one had a master's degree in German, 28 teachers had bachelor's degrees in German, 13 teachers took part in the transformation programme, 2 had certificates of German teaching, and 1 had a ZMP certificate (the certificate of German language Intermediate Level).

${ }^{31}$ For English teachers, not all teachers have had a chance to go to English-speaking countries for training or other experience. This affects the effectiveness of teaching because experience in a country where the language being taught is spoken helps build confidence.

${ }^{32}$ Boonchim, 1999: 74.
} 
Arts or Faculty of Humanities, but not for those from the Faculty of Education (91.1\%).

The lack of the German language teachers led to the closure of German language programmes in recent years, even at famous high schools with long-standing German programmes like Sai Panya School, Satri Mahapruttharam School, Wat Makutkasatriyaram School, Santirath School and Prakanong Pittayalai School. Many others will soon follow the path. However, in the meantime, German language courses are being offered at some public high schools, as for example, Triam Udomsuksa Pattanakarn School, Kanchanaphisek School in Nakorn Pathom, Kaen Nakorn Withayalai School in Khon Kaen, and Pattalung School in Pattalung, as well as Joseph Uppatham School, a private institution.

\section{The current cause of the decreasing number of German language teachers and students (2004):}

The cause can be divided into two parts: the teachers and the students.

\section{Teachers}

\section{The retirement of German teachers}

The retirement of German language teachers caused vacancies which were supposed to be filled by new German language teachers. However, in reality, the vacancies were not reserved for German language teachers and the decision to fill the vacancies depends on the school's administration and the need for teachers of other subjects.

\section{The teaching career}

Teaching, it can be said, is less attractive than other careers because of the heavy workload and relatively low income. School teachers sometimes may be assigned to teach other subjects than their own specialization, totaling about $18-24$ hours per week. These are exclusive of administrative work. Moreover, the number of students per class is disproportionate to the number of teachers.

For these reasons, the teaching career is relatively unattractive to graduates majoring in German. The private sector, for example, German corporations, embassy, and foundations, makes a better choice in terms of income and promotions.

\section{Students}

\section{Globalization and the popularity of neighbouring languages}

In Thailand, most students learn English as their first foreign language and French or German as their second foreign language, respectively. Due to globalization, people have been active in learning foreign languages other than English. This can be seen from various foreign language services on television and radio, and in newspapers and films. Therefore, Thai people are more used to foreign languages, in particular Japanese and Chinese.

For years, Japanese and Chinese have been offered at the high-school level. Apart from German and French, Japanese has been one of the foreign language options offered on the entrance examination. For this reason, Japanese and Chinese are more popular than the European languages. 


\section{Fewer job opportunities for German majors}

It is supposed that the greater the investment from German speaking countries, the more job opportunities there are for German majors. However, it seems that German language proficiency is not a factor for employment because communication in German firms is effected in English. In contrast, Japanese firms prefer Japanesespeaking staff. Some fourth-year students majoring in Japanese are offered jobs before they graduate. Moreover, many scholarships to Japan for research and further study are also offered. ${ }^{33}$

\section{Attitudes among German language teachers at high-school level}

A survey by Boonchim (1999) of attitudes among German language teachers at the highschool level shows that most teachers had a good attitude towards teaching. To them, teaching is a secure and highly respected career. The success of students made them proud of themselves and made them eager to improve their language competence and teaching.

\footnotetext{
${ }^{33}$ Due to greater job opportunities with Japanese or other foreign languages, most students who chose German on the entrance examination discontinue German and learn other new languages, which do not have prerequisite knowledge. This is because German is difficult and job opportunities are limited. Japanese, Chinese, Italian, and Spanish seem to be better choices. For Italian, the students reason that it is offered only at the Faculty of Arts, Chulalongkorn University. Spanish is one of the five languages used at the UN and is spoken in many countries apart from Spain.
}

As for the qualities of good German language teachers at the high-school level, most high school teachers (more than $90 \%$ of those surveyed) thought that German language usage, knowledge about Germany, and teaching methods were the most important and should be "very good" or "good". Other fields of knowledge should be "good" or "appropriate", for example, German linguistics, literature, history, society, and politics.

For German language lecturers at the university level, most high-school teachers felt that they were expected to have more expertise in the following fields:

German language usage, German linguistics and literature, Knowledge about Germany, German history, society, and politics. ${ }^{34}$

Greater expertise in teaching methods is also expected. However, the most important quality for those at both the high-school and university levels is eagerness to teach and to learn.

According to the high-school teachers, German language teachers at the high-school level should have at least one year of experience in Germany, while university instructors should have 2-3 years of experience.

\footnotetext{
${ }^{34}$ Boonchim, 1999: 77.
} 


\section{Expectations of and attitudes towards German teaching among high-school students}

In 1999, a survey was conducted by Tienboonlertrat and Chanbanditnan to determine the expectations of and attitudes towards German teaching among high-school students. The respondents were male and female students, aged 14-20, in grades 10, 11, and 12, from ten high schools in Bangkok. Most of them were 16-17 years old.

\section{Expectations of the high-school students:}

The survey showed that the German language was interesting, as expected, but it was difficult, i.e., German is in reality not easy to learn. However, it gave them job opportunities, for example, teaching etc. What did meet their expectation was that those who wanted to learn German needed to be good in English. Moreover, they were disappointed that they had less chance to use German in daily life. Regarding expectations towards teachers, there are several of them:

a. What did not meet the students' expectations was the lack of native German teachers at the high-school level.

b. What met their expectations was that Thai teachers could speak German well $(94.2 \%)$. They had knowledge about Germany $(88.7 \%)$ and had lived in Germany (88.4\%). They could also teach well and made students enjoy class $(85.7 \%)$. Moreover they were friendly and not strict with students $(84.6 \%)$. This shows that Thai teachers were seen as competent. The expectations of students corresponded to the teachers' abilities.

As for schools, it was expected that nonclass activities would be provided but they were not. The survey showed that, in general, most of the students (in grades 10, 11, and 12) had good attitudes towards German, as follows:

"German can be selected in doing the entrance examination".

"German has opened me up to the outside world".

Second to these opinions were:

"Although German is difficult, I am willing to learn it".

"Although German is difficult, I have gained advantage from it."

In sum, they were not disappointed that they had studied German. Based on the survey mentioned above, the following ideas for improving teaching can be drawn:

a. The school should provide more activities related to German.

b. In general, the respondents were not interested in information about Germany, news, politics, sports, culture, or the economy. This must be improved because language and culture cannot be separated. Interest in the German language should go along with an interest in German culture, as they complement each other.

c. Skill in communicating such a difficult subject as German, supplementary activities to the teaching, and a cosy atmosphere in the class should be 
retained. These affect the students' attitude towards German.

d. Social and cultural information about Germany, in Thai or German, should be introduced to the students. To encourage students to speak German, the following activities should be organized: German essay and narration contests, invitation of native speakers to the class, exhibitions, pen friends, student exchange programmes, and German students majoring in German as a Foreign Language should be encouraged to teach in Thailand.

e. German grammar should not be emphasized more than the other four skills because these skills-listening, speaking, reading and writing-will lead to the integration of knowledge. Tests or examinations should be based not on the correct use of grammar but on success in communicating. To put it simply, the correct use of grammar does not guarantee good communication in a given situation.

\section{The development of textbooks at high-school level}

As mentioned before, the textbook series Viel Spaß mit Deutsch was the first German language textbook written by Thai teachers in cooperation with the Goethe Institute Bangkok and the head office in Munich. In comparison with other textbooks at the high-school level, Viel Spaß mit Deutsch is quite modern (although in use for more than 15 years already) because it takes a student-oriented approach with the following characteristics: a. Communicative skills were emphasized more than grammar.

b. Conversational and reading topics were selected based on the ages and interests of students. Before the book was produced, surveys had been conducted.

c. Communication in different daily situations was emphasized to encourage communication with native speakers.

d. The role of Thai learners was emphasized in order to encourage Thai students to disseminate Thai culture to native speakers. Therefore, students learn a lot of German terms, vocabulary and expressions about Thai culture and this encourages crosscultural communication. Students can compare their own culture with the German one. ${ }^{35}$

Now government educational reform has unfortunately led to a change in using new German textbooks such as Ping Pong, Delphin and Genial in many schools. Most teachers felt that Viel Spaß mit Deutsch needed revisions, and so prefer using modern textbooks from Germany.

\footnotetext{
${ }^{35}$ From textbooks produced by Germans, students learn only about German culture but cannot express their own culture in German. Arguably, there are related questions about the learner's country and culture. However, it is not sufficient, especially in building the German lexicon of the learners' culture. For these reasons, German textbooks with the content of Thai culture are necessary and this will encourage students to learn German because what they learn can be used, to communicate with German-speaking people about their own experiences.
} 


\section{German language teaching at the university level}

\section{Curriculum}

Today, German is offered at ten universities, both public and private. The public and private universities which offer German as a major are Chulalongkorn University, ${ }^{36}$ Thammasat University, Silpakom University, Chiang Mai University, Kasetsart University, Srinakarinviroj Prasarnmit University, Prince of Songkla University, Ramkhamhaeng University, Khon Kaen University and Payap University. Mahidol University is considering offering German as a major, minor, and other higher level courses, after having cancelled elective German courses in the Faculty of Sciences. The only private university which offers German as an elective course is Assumption University.

The offering of German at the university level must comply with the undergraduate curriculum regulations of 1999 , which require a total of 120 credits. These can be divided into three groups:
a. General sciences (not fewer than 30 credits)
b. Specialized courses (not fewer than 84 credits)
c. Elective courses (not fewer than 6 credits)

\footnotetext{
${ }^{36}$ German is offered as major and minor subjects for undergraduate students of the Faculty of Arts and the Faculty of Education.
}

Based on the structure above, each university may have different concentrations and each is required to improve the curriculum. For example, under the revised undergraduate curriculum of the Faculty of Arts, Chulalongkorn University (2003), students are required to complete 147 credits, divided into the following parts:
a. General education
30 credits
b. Specialized courses 111 credits sub-divided into:
- Foundation courses in Arts 40 credits
- Concentration courses 71 credits (German as major 51 credits)

c. Elective courses 6 credits

In general, the curriculum for German majors and minors at all universities consists of the following five components: ${ }^{37}$

\section{Communicative skills courses}

These courses emphasize the four communicative skills of listening, speaking, reading, and writing. Each skill can be studied separately or in an integrated manner. In general these courses are available because they are the foundation for higher courses and research as well as for communication with German speaking people in daily and professional life. Skill courses are normally offered in the first and second years, continuing from the three years of study in high school. In addition, grammar courses are also provided.

\footnotetext{
${ }^{37}$ Saengaramruang, 1995: 281.
} 


\section{Cultural and social courses}

Based on the idea that languages cannot be separated from their corresponding cultures, courses on German culture and society are provided. This leads to the understanding of the mentality of Germans and other German speaking people and, in turn, contributes to trade and international relations. Moreover, the knowledge of other cultures brings about peace and urges people to reflect on their own cultures. Therefore, languages open up the world and contribute to mutual understanding between nations.

\section{Literature and literary history}

German literature forms part of Germanistik in Germany, which deals with prose, poetry, plays, the literary history of each era, literary interpretation, and literatures of Germanspeaking countries. The literature courses provided in the universities range from introductory courses to courses on specific eras or authors. Literature is crucial to the study of the humanities because it leads to an understanding of the nature and mentality of each nation. However, literature courses tend not to be popular because they don't contribute directly to work life.

\section{Linguistics courses}

These courses deal with the analysis of language in terms of structures and characteristics of different text types. These courses form the basis of linguistic research, especially contrastive studies.

\section{Profession-oriented courses}

These courses include German for Tourism, German for Business, German-Thai and
Thai-German translation. These courses are only an introduction to each field. At present, apart from translation courses, which have been offered since 1957 more professionoriented courses are being provided because they are more concrete than literature and, thus, easier to apply to a future career.

At present, different German courses are being made available to students from other faculties, as seen in the courses provided by the Faculty of Arts:

a. German for beginners 1-4, each 2 credits for students of Arts and other faculties, without basic German knowledge;

b. German for students from the Faculty of Political Science 1-3, each 3 credits and requiring 3 years' German study in high school;

c. German for music students from the Faculty of Fine Arts, 1 credit, upon the request of the faculty;

d. German youth literature in Thai as a course in the general education for all students;

e. Fundamental German 1-2, each 3 credits for students from the International Programme of the Faculty of Economics, without basic German knowledge;

f. In 2007, 2 basic courses in German culture and language, each 3 credits, will be offered to students in the International Programme of the Faculty of Engineering, Department of Automobile Engineering, and Department of Nano Engineering.

In the course of 50 years, German language teaching has branched out to other faculties 
with different needs. It is noted that most new courses are specialized ones, for example, German for Political Science or Engineering. That is to say, they are increasingly future career-oriented because Germany is well known for heavy industry and technology. For this reason, German language teaching has not concentrated on grammar. Moreover, specialized fields such as literature are not popular. What is still needed are introductory courses in literature, especially for those without German language knowledge. After all, German cultural courses are still needed along with communicative skills courses because they can serve as basic knowledge for continuing study in Germany, Switzerland, or Austria.

\section{The German programme in Thailand and Germanistik in Germany}

Germanistik is a term for the study of German language and literature. It is an undergraduate programme in Germany with a concentration on linguistics or literature. In addition, other courses are required, for example, pedagogical and philosophical courses. In comparison with German programmes at the university level in Thailand, Germanistik is equivalent to a master's degree because, in the past, the bachelor's degree system was unknown in Germany. ${ }^{38}$

\footnotetext{
${ }^{38}$ At present, the German educational system after high school has been restructured into bachelor's and master's degree programmes which are more open to international students and allow for easier credit transfers.
}

As for the German programme in Thailand, it was, in the past, designed by German lecturers in the Faculty of Arts. Due to the lack of communicative skills and knowledge about Germany, most courses in the first and second years were communicative skills courses and courses regarding knowledge about Germany. Historical and literary courses as well as translation courses were given in the third and fourth years. Those interested in German linguistics and literature had to continue their studies at the graduate level. The study of German outside Germany is called Auslandsgermanistik, or 'German as a Foreign Language'. Its scope is wider than the traditional Germanistik in terms of the foreign learner/user-oriented approach with the following foci:

a. External factors affecting German language learning, for example, the mother tongue of learners, behaviours and experience in foreign language learning, general and specific problems in German language learning, and curriculum design at different levels appropriate to different regions.

b. Foreign language teaching-oriented research for higher effectiveness in German language teaching over shorter periods. In doing this, mother tongue and behaviours of learners will be taken into account and applied to German language learning.

\section{Development of the undergraduate curriculum}

Considering the development of German language programmes at the university level from 1957 until now, German language 
programmes have been curricula offered at various universities, and the curricula have been revised, improved, and developed to meet demand.

In 1974, the master's degree programme in German was first offered by the Faculty of Arts, Chulalongkorn University. Then, Ramkhamhaeng University followed in 1999 with a master's degree in German as a foreign language. In 2006, Chulalongkorn University plans to offer a doctoral programme in German.

As regards translation and interpretation studies, a German-Thai and Thai-German programme cannot be offered at present due to a lack of staff. However, a curriculum was developed in conjunction with the Department of English and the divisions of French, German, and Japanese. The master's programme in translation and interpretation (English and French) was launched in 1999. ${ }^{39}$

Now every university which offers German language courses makes regular changes intended to make the curriculum more practical and to encourage students to learn German on their own. To realize these aims, self-learning centers and audio-visual materials such as Internet and satellite broadcasting are provided, and non-class activities are encouraged, for example, German language camps and parties. In the camps, students from different years have a chance to get to know each other and their lecturers. At parties organized by the Goethe Institute, various activities are organized, for

${ }^{39}$ See more at O'charoen (1998: 71-75). example, singing, plays, films, poetry recitals, quizzes, and essay contests.

Attempts to improve German language teaching and students have taken different forms including the following:

a. Academic cooperation between Thai and German universities. For example, contracts have been signed between the Faculty of Arts at Chulalongkorn University and the University of Kassel, the University of Siegen, and the University of Heidelberg. Under these contracts, Germanistik professors from the University of Siegen came to lecture for a month at Chulalongkorn University. Graduate students have been allowed to attend classes and do research for a semester in the University of Siegen. Thammasat University has cooperated with the University of Hamburg and the Technische Hochschule München, and Ramkhamhaeng University with the University of Leipzig.

b. Cooperation with different organizations offering academic support. For example, the GermanThai Society granted scholarships to Thai students to be apprentices at the DAAD and to be assistants at various universities, such as the University of Münster.

c. Cooperation with international networks such as IQN, an international network for German as a Foreign Language based at the University of Kassel. Its contribution is to organize conferences for new research on related topics. 
d. Encouraging German students majoring in German as a Foreign Language to teach in Thailand, which contributes to their studies, i.e., they will gain experience and earn a certificate. They will experience the problems faced by Thai students in learning German and acquire some familiarity with Thai culture. Thai students will have a chance to meet native speakers.

e. Various non-class activities are encouraged, for instance, interpreters in trade shows, cultural exhibitions and other activities. To do these activities, coaching teachers need to provide guidance. Non-class activities are more and more important because they help prepare the students majoring in German for a future career, i.e., they will come to understand market demands and trends. Moreover, they are sometimes well paid.

Apart from some high schools, universities, and the Goethe Institute, the German language can be learnt from other media. The internet is one such channel, for example, www.goethe. $\mathrm{de}^{40}$ or the radio classroom (since 1975) by the Ministry of Education at FM 92 MHz or AM $1161 \mathrm{kHz}$ every Tuesday, 7:30 8:00 and 18:30-19:00.

\footnotetext{
${ }^{40}$ See more at Kaewwipat (2001: 137-139).
}

\section{Undergraduate institutes which produce German language teachers in Thailand}

\section{The Faculty of Education, Chulalongkorn University}

The Faculty of Education, Chulalongkorn University was the first undergraduate institute to offer pedagogical German. ${ }^{41}$ In the first two years, students join German language classes with students from the Faculty of Arts. The rest of the programme deals with general subjects required by the Faculty of Education, German language teaching and teaching practice. In addition to German, students are required to major in another subject as well.

In 1997, a special project named "Kharu Tayaat" (descendants of education) was initiated to produce German language teachers. Applicants are students in grade $12^{42}$ or high school graduates with a GPA not less than 3.00. They are also required to pass other examinations. The number of students in this project is limited to five per year. Students majoring in German will be granted a scholarship to take the ZDAF (the certificate of German as a foreign language) course. Those who have graduated and are

\footnotetext{
41 In the first few years after the university's founding, education students attended German classes according to the German programme for education students provided from the Faculty of Arts and Science (3-4 Years). See more at Festschrift (1967: 5, 21).

${ }^{42}$ For more information, see the Announcement of Chulalongkorn University regarding non-formal admission to the Faculty of Education.
} 
teachers will be considered by the Goethe Institute for a training course in Germany.

This project shows the effort of the Faculty of Education and the Goethe Institute to address the lack of German language teachers.

Recently the pedagogical curriculum at the undergraduate level was revised, i.e., it was changed from 4 to 5 years throughout the country. Under this revised curriculum, pedagogy students gain more experience in real teaching and, thus, become more effective teachers.

\section{The German Section, Faculty of Arts, Chulalongkorn University}

Since 1974, the Faculty of Arts has offered a master's degree programme in German. The curriculum is similar to Germanistik in Germany, which concentrates on language and literature, and is considered highly academic. After finishing their coursework, students are free to do research in German as a foreign language, literature, linguistics, or translation studies, which may contribute to their careers in the future.

The students who enter the programme are mostly university lecturers and high-school teachers. The theses and research on German language teaching have increased and contributed to the research mentioned in this paper. Research has also been published in various journals, for example, the Journal of German Language Teachers in Thailand (TDLV-Forum).

\section{The Division of German, Faculty of Humanities, Ramkhamhaeng University}

The master's degree programme in German as a Foreign Language has been offered since 1999. This programme is offered on weekends and divided into two types: Plan A with thesis and Plan B with and without special research. It concentrates both on theory and practice. Ramkhamhaeng University has also issued a journal named Die Brücke: Zeitschrift für Germanistik in Südostasien since 2002.

\section{Research to make German language teaching in Thailand more effective}

Apart from the textbooks, the development of German language teaching can be seen from the increased number of studies concerning the way to make German language teaching more effective during this decade. This greater effectiveness can be proven by the following improvements:

\section{German language textbooks/school books}

The development of textbooks is quite obvious, starting from the adoption of German textbooks produced in Germany in German classes in Thailand to the production of German textbooks by Thai teachers for Thai students. ${ }^{43}$ This shows that the

\footnotetext{
${ }^{43}$ This refers to the textbook series Viel Spaß mit Deutsch, which is the first German textbook series produced by Thai teachers at the high-school level. There is also a new German textbook for adult learners in the production process: Deutsch für Anfänger I, Deutschunterricht für Thailänder
} 
development of textbooks has progressed in line with the recent education reform, which emphasises the learner-oriented approach. In other words, the Viel Spaß mit Deutsch series has aimed at motivating learners to communicate their own stories, regarding, for instance, family, Thai society, and Thai culture and traditions, in German with German speaking people.

Unfortunately, some high schools are, at present, opting to use German produced textbooks instead of ones written in Thailand. It is true that the textbooks written by Thai teachers have become outdated; however, revisions or modifications can be made. Therefore, the issue of German textbooks should be seriously discussed in order to determine which goals to strive to achieve.

\section{A variety of German language textbooks, reference and handbooks}

At present, there are a variety of textbooks, reference works, and handbooks which help improve teaching. For example, there are a series of German grammar books, a variety of German-Thai/Thai-German dictionaries, specialized dictionaries for tourism and politics, and translation textbooks. Moreover, a lot of German literature, such as classic German literature and youth literature, has been translated into Thai in order to introduce the German lifestyle, culture, people, and ways of thinking to Thai learners, because culture is a part of language learning.

(German for Beginners 1, German for Thai Learners) by Phanda Tamura and Rudee Palanuwech, of Thammasat University.

\section{The increased amount of comparative Thai-German research}

For years, German-Thai comparative research on a wide range of topics has been conducted in order to improve German language teaching. This research can be classified into the following groups:

a. Linguistic structure: comparative study of compound words in German and Thai, negations in German and Thai, relative clauses in German and Thai, and the study of German particles ('Abtönungspartikeln') as illocutionary indicators and their counterparts in Thai, etc.

b. Problems in learning German among Thai students, for example, article use, etc.

c. Research for improving and developing curricula and teaching, for example, undergraduate curricula, tele-teaching curricula, etc.

d. Research on the textbook series Viel Spaß mit Deutsch, for example, the image of Germany and Thailand, visual media (pictures) for teaching in Viel Spaß mit Deutsch, etc.

e. Research on cultural issues: "Collaboration among German and Thai Staff: A Case Study of Opinions towards Communicative Behaviours of German and Thai Staff at the Goethe Institute", "German Culture in the Undergraduate Curriculum for Major Students", "Thailand's Image in the German Media", "Food and Drink in Vocabulary and Idiomatic Expressions of German and Thai", etc. 
Although German has been taught in Thailand for more than 80 years, the development of textbooks for more effective teaching has been relatively slow and a lot of fundamental teaching media are still needed in order to encourage Thai students to do selfstudy for better communication with German speaking people, business people, and others.

\section{Survey of language awareness ${ }^{44}$ among high-school students who learn German}

Apart from technological innovation, it cannot be denied that German has been influenced by English, in particular American English. The influence can be traced back to the end of World War II, when Germany was governed by America, England, and Russia. Economic support under the Marshall Plan had a particularly great influence. It appears quite normal that many English words and terms have prevailed not only among teenagers but also academics, for example, Internet, Wellness, Fitness-Center, and last but not least, Hochschulmarketing. Because English is the most popular second language learnt by people in non-English-speaking countries and French or German come in third place, the English knowledge of German language learners is used as a guideline for teaching, e.g., German vocabulary. This approach has been popular in Germany and many other EU countries.

To survey the advantage of tapping the English knowledge of Thai students learning German, language awareness was tested in

\footnotetext{
${ }^{44}$ In German 'Sprachbewusstheit'.
}

order to improve German language teaching. In 2003, a language-awareness ${ }^{45}$ test for German as a third language ${ }^{46}$ was conducted for the first time in Thailand ${ }^{47}$ among students at five high schools in Bangkok. ${ }^{48}$ Among them were 125 grade 10 students, aged 15-16, with German knowledge of 2 semesters (approx. $144 \mathrm{hrs}$.), and 80 grade 12 students, aged 17-18, with 6 semesters of German knowledge (approx. 528 hrs.) Each group of students had learnt English for 12 and 15 years, respectively. The objective of the survey was to investigate the contribution of English to German language learning.

The results showed that more than half of both groups had no idea about what the German language was like when they first began to study, and almost $40 \%$ of the test groups noticed that German and English were similar. Apart from German, both groups of students had also learnt other languages, such as French, Chinese, Japanese, Spanish, and Korean.

As for pronunciation, the study showed that some grade 10 students use their English knowledge as a reference in learning German. For example, the diphthong 'ie' in German is equal to the vowel 'e' /i/ in English, and the

\footnotetext{
${ }^{45}$ Language learners will observe their learning process, develop their own language-learning strategies and improve their language competence by self-evaluation.

${ }^{46}$ Thai is the mother tongue; English the second language; and German, the third.

${ }^{47}$ Saengaramruang (2003: 165-90). See more at Kusolrod (2003: 42-49).

${ }^{48}$ These include Triam Udomsuksa School, Satri Withaya School, Surasakmontri School, Bodindecha School, and Taweethapisek School.
} 
diphthong 'ei' in German to the vowel 'i' /ai/ in English. Moreover, they noticed that many words in both languages are similar but differ in pronunciation. What is crucial to Germanpronunciation teaching is interference from English pronunciation, as shown with more than $1 / 2$ of the grade 10 students. Interference often happened in such words as Fußball, Pizza, Buch, Bier, ist, Telefon, Salat, Musik, Haus, etc. Moreover, students frequently had problems with words with an umlaut ( $\ddot{a}, \ddot{o}, \ddot{u}$ etc.) For the reasons mentioned above, the pronunciation of German words which are similar to English, such as Familie, Tee, Auto, Musik, and Problem, etc., should be taught separately. ${ }^{49}$

As for lexical items, both groups could guess the meaning of German words by comparing them with English. Examples include Adresse, Apfel, Auto, Banane, Beginn, Aktion, akzeptieren, Bank, Bier, Buch, diskutieren, etc. However, there is also the problem of false cognates. For example, the words Gift and See in German mean 'poison' and 'sea/lake', but, in English, they mean 'present' and 'visual perception', respectively. The former is pronounced similarly in both languages but the latter is pronounced /ze:/ in German but /si:/ in English. The word 'die' in German is a feminine definite article, pronounced /di:/ but /dai/ with the meaning of 'stop living', in English. The word Gymnasium means 'high school' in German but 'sports hall' in English.

\footnotetext{
${ }^{49}$ See more at Saengaramruang (2003: 173-77).
}

The findings of the research can be used to improve German teaching. Exercises should be made to raise awareness of English interference, and students should be drilled. The differences between German and English should be introduced and taught at the beginning.

Regarding reading and, the use of technique of Internationalismen ${ }^{50}$ (similar linguistic forms) by beginning learners, Research showed that the grade 10 students have more language awareness than those in grade 12 . To put it more clearly, the grade 10 students used more of their knowledge of other foreign languages to read German texts. Therefore, Internationalismen, i.e., guessing meaning from another foreign language that learners have studied before, such as English, French, or Italian, can perhaps contribute to the teaching of reading in the case of such words as Zeremonie, Präsident, Olympiade, Beginn, Nation and Parade. The approach of 'Internationalismen' or 'German as a third language after English' can be applied to teach reading of a German text because it motivates Thai students to a more effective learning of German and makes German language learners feel that German is not difficult. $^{51}$ However, this approach has not been adopted in Thailand. ${ }^{52}$

\footnotetext{
50 Internationalismen refers to a group of words which are similar in form and meaning among various languages derived from the same root, frequently Latin, for example, Elefant/elephant, elegant/elegant, Fisch/fish, Foto/photo, etc.

51 For more information about the result of the research regarding German pronunciation and vocabulary teaching, see Saengaramruang (2003: 2).

52 For a pilot textbook which tries to adopt the technique of learning German as a third language
} 


\section{Survey of German language students at university level}

Due to the relative lack of success in teaching English as a second language, one of the most frequently asked questions is which skill, among the four skills of listening, speaking, reading, and writing, is the most important for Thai people to learn in a relatively short span of time and be able to use effectively? In Thailand, a lack of research on this issue hinders the improvement of foreign-language teaching and the formulation of a national policy.

A survey was conducted in the second semester of 2004 to find out the hierarchical order of skills in language learning at two universities, Chulalongkorn University and Silpakorn University, by means of a questionnaire for students majoring in German in every year. ${ }^{53}$ At Chulalongkorn University, 56 of $58(96.6 \%)$ respondents returned the questionnaires, and at Silpakorn University 96 of $113(85.95 \%)$ did so. The result of the survey is significant for further improvement of the German language programme at the university level.

Regarding the four skills, the two most important skills for a future career are

after English ('Deutsch als Tertiärsprache nach Englisch') for Thai learners, see German for Communication by Wanna Saengaramruang (in production).

${ }^{53}$ This survey was conducted as a term paper by master's programme students, course 2232 657, 'German as a Foreign Language', $2^{\text {nd }}$ semester 2004, Faculty of Arts, Chulalongkorn University. speaking and listening, as determined by the students of both universities (speaking slightly higher); then follow the skills of reading and writing. That is to say, the hierarchical order of skills in language learning is speaking, listening, reading and writing. However, priority is given to reading, and writing, because reading, it is believed, is the fundamental skill for the other skills. In addition, the students of both universities shared the same point of view that reading and writing should be given less priority and that the skills of speaking and listening should be emphasized more.

As for future careers, they also shared the same ideas but in different order, i.e., flight attendants, German firms, and the embassies of German-speaking countries. For Chulalongkorn University students, German firms are the first priority, then the embassies, and finally flight attendants. For those from Silpakorn University, becoming a flight attendant is the most popular, then German firms, and the embassies. The least popular careers are German teaching and civil service. The survey suggests that the German programme at university level should put more emphasis on the skills most needed for these three popular careers.

As regards the subjects considered important for the students, they can be classified into five groups as follows:

For those from Chulalongkorn University, communicative skills subjects $30.4 \%$, careeroriented subjects $20.6 \%$, cultural and social courses $18 \%$, linguistics courses $15.3 \%$ and literature courses $14.6 \%$.

For those from Silpakorn University, the result was quite similar, that is, 
communicative skills subjects $32.1 \%$, careeroriented subjects $22.3 \%$, linguistics courses $17 \%$, cultural and social courses $15.7 \%$, and literature courses $12.9 \%$.

In conclusion, literature courses are the least popular (14.6\% and $12.9 \%$, respectively), and the most popular ones are communicative skills subjects $(30.4 \%$ and $32.1 \%$, respectively) and career-oriented subjects (20.6\% and $22.3 \%$, respectively).

\section{The survey and possible modifications to German language teaching at university level}

If, as shown in the survey discussed above, communicative skills subjects and careeroriented subjects are seen as priorities, the question is whether or not current German language teaching should be modified. In other words, should courses be geared towards future careers and should content, curriculum, and policy be more learnercentered? The attitude to foreign-language learning has changed from knowledge for knowledge's sake to knowledge for practical use. Therefore, in order to respond to the needs of learners today, it is important to give emphasis to foreign language teaching that prepares students for careers after they graduate, in addition to the conventional approach, i.e., language learning for academic, cultural, or humanities-related purposes. These are not as important for undergraduate students nowadays as communicative skills for future careers. Modifications to the curriculum must be considered by the parties concerned.

Yet, despite the views of current learners, the traditional goals of a liberal-arts education must not be discarded. Foreign language teachers must make learners aware of the value of literature and linguistics courses as a mirror on the culture of the speakers of the foreign language. They are important for building cross-cultural bridges and giving insights into the ways of thinking of people from other countries. If traditional humanities courses are entirely eliminated in favor of more career-oriented offerings, the university ceases to be a place for intellectual activity and becomes merely a vocational institute. For this reason, it is vital to maintain the core values of the traditional liberal-arts education.

\section{Support organizations and activities for German language teaching in Thailand}

\section{The Association of Teachers of German in Thailand}

The Association of Teachers of German in Thailand (ATGT) was established by the support of the Goethe Institute in 1993 for the purpose of encouraging the teaching of German language and the exchange of German culture, academic topics, and experience among teachers. ${ }^{54}$ To achieve these purposes and disseminate research, an annual journal TDLV-Forum, Zeitschrift für Sprache, Literatur und Kultur is issued. Moreover, there are also a variety of activities, for instance, Deutscher Tag (German Student Meeting), which is organized for student exhibitions, contests, singing and stage shows, the biannual International Associations of German

\footnotetext{
${ }^{54}$ Srikeaw (2002: 33).
} 
Language Teachers, and the bimonthly meeting of German language teachers.

\section{Germanistentreffen Conference}

The Thailändisches Germanistentreffen Conference is held biannually with an aim to disseminating research by German teachers in Thailand. The rationale of the conference is to provide a platform for German language teachers and lecturers. The $1^{\text {st }}$ conference was organized on 4-5 October 2001 by the German Section of the Faculty of Arts, Chulalongkorn University. ${ }^{55}$ The second was organized by Ramkhamhaeng University on 7-8 October 2003, and the third by Chiang Mai University on 24-25 March 2005. The fourth will be held by Thammasat University in 2007. The objectives of these conferences are as follows:

a. To disseminate research by German teachers and lecturers;

b. To encourage an exchange of German language teaching ideas and update knowledge;

55 At the first conference, there were 100 participants, including 81 Thai and native lecturers and teachers from 30 institutes that offer German language, i.e., from 9 universities, 20 schools, and the Goethe Institute. There were also three German teachers form Laos. The other participants were graduate students from Chulalongkorn University and Ramkhamhaeng University and guests. The conference was presided over by the Rector of Chulalongkorn University, Assoc. Prof. Tatchai Sumitra, and the former German Ambassador, Andreas von Stechow. See more at 1. Thailändisches Germanistentreffen or the journal TDLV -Forum 7/2002. c. To create an academic network of German language teaching;

d. To improve the quality of teaching at high-school and university levels;

e. To encourage research on German language teaching that will keep teachers alert and respond to the educational reform initiated by the government. ${ }^{56}$

The conferences are supported by the Association of Teachers of German in Thailand in cooperation with related organizations, including the DAAD, the Goethe Institute, the Supervisory $\mathrm{Unit}^{57}$ of the Ministry of Education, high schools, and universities.

\section{Foreign support}

DAAD (Deutscher Akademischer Austauschdienst), a German organization for academic exchange, was the first and most important organization to provide support in German teaching at the university level. The first German native lecturer (DAAD-Lektor), Dr. Georg Heuser, was sent to the Faculty of Arts in 1957 and many were sent to other universities in Thailand, for instance, Thammasat University, Ramkhamhaeng University, Chiang Mai University and Khon Kaen University. At present, support has been cut and in the future German lecturers will be

\footnotetext{
${ }^{56}$ Saengaramruang (2002: 26-27).

${ }^{57}$ Due to educational reform and restructuring of the Ministry of Education, this office was abolished. Additionally, educational areas were divided, and, as a result, no central office is responsible for German language teaching in Bangkok or other regions.
} 
sent only to Chulalongkorn University (Faculty of Arts), Chiang Mai University (Faculty of Humanities), and Thammasat University (Faculty of Law). ${ }^{58}$

In addition, the DAAD grants scholarships to Thai lecturers wishing to do doctoral research in Germany. Scholarships are not limited to German language and literature but are also granted to Thai lecturers in the sciences, for example, medicine and dentistry. There are short-term scholarships (two months) for master's programme students to do research in Germany, scholarships for DAAD Alumni members, summer scholarships for undergraduate students, etc. Moreover, the DAAD also cooperates with the Thailand Research Fund in supporting doctoral research.

Another key support organization is the Goethe Institute. Its contribution to German language teaching in Thailand dates back to 1968, when there was a lack of German language teachers and courses. To solve this problem, the 'The German Language Transformation' project was initiated to train English or French teachers to teach German. Seven teachers were sent to Germany for training with the support of the Goethe Institute. Among them were Suwannee Pratumrat of Sai Panya School, Banchuen Thanakhom of Triam Udomsuksa School, and Sudsawaeng Rakkhumkaew of Suksanaree School. About thirty years later in 1993, 1995, and 1999, a second phase was made available to solve the problem of the

\footnotetext{
${ }^{58}$ DAAD has been sending a language assistant to the Faculty of Arts, Chulalongkorn University, since 2003, after one to Khon Kaen University.
}

lack of German language teachers. Twentynine teachers were trained (five resigned in 2004). German was offered in 12 more high schools. To keep teachers up-to-date, a weekly seminar has been organized and some teachers were granted scholarships to Germany.

In the end, both the DAAD and the Goethe Institute are major supporters and advisors to German language teaching in Thailand over the last 50 years, the former at the university level and the latter at the high-school level. Their support can be summarized as follows:

\section{Regarding teachers:}

DAAD: Longer-term scholarships, for example, doctoral or other research

Goethe Institute: short-term scholarships for training or keeping up-to-date

\section{Regarding students:}

DAAD: Research and summer scholarships at various universities in Germany

Goethe Institute: Training and summer scholarships at the Goethe Institute in various cities in Germany

\section{Regarding visiting professors:}

DAAD and Goethe Institute: Lectures by professors or specialists from Germany

\section{Regarding teaching media:}

DAAD and Goethe Institute: Teaching media such as books, in particular films and videos, in cooperation with Inter Nationes. Former DAAD students are allowed to apply for 
research scholarships and may obtain necessary textbooks for their research within the budget provided.

\section{Conclusion and Epilogue}

\section{The learner-oriented approach: The key to Thailand's educational reform}

At present, foreign-language teaching approaches have been made more learneroriented, according to Neuner, in terms of curriculum design or teaching plans by taking into account the following factors:

a. The use of background knowledge of learners: mother language or other foreign languages of learners, knowledge about social background, experience of language learning;

b. The purposes, needs, expectations of learners to learn this new foreign language: Why should we learn this new language?

c. The learning environment: Where and in which circumstances to learn this new foreign language; chances to use this new foreign language in the learners' environment? ${ }^{59}$

After having taken the factors mentioned above into account, the following aspects must be emphasized in German language teaching:

59 From the keynote speech in Thailand's first Germanistentreffen Conference by Prof. Dr. Neuner, specialist in German as a Foreign Language, University of Kassel, Germany. See more at Neuner (2002: 45-53). a. Learning techniques based on experience with other foreign languages: Most learners usually learn German as a second or third language after English. Thus, techniques of vocabulary learning and, reading skills can be exploited in German teaching.

b. The relationship between the English and the German language that can be used in German language learning, for example, the similarity of English football and German Fußball.

How much do we have to take the learneroriented approach mentioned above, which is also the key to Thailand's educational reform, into account in the development of German language teaching in Thailand?

\section{Pending questions}

There are several pending questions. Below are some of them:

\section{Question 1: What is the interpretation of the Educational Reform Act, and what are the objectives of German language teaching at the high-school level?}

The textbook series Viel Spaß mit Deutsch has been used for more than 15 years. These textbooks were produced based on learneroriented approaches analyzed earlier. Extensive research on this textbook series has been conducted. The question is whether or not it is appropriate to stop using Viel Spaß mit Deutsch in many high schools. 
Revisions of the textbooks should be made by teachers who teach German because they know and understand the students best. The participation of German language teachers in revising the textbooks will give them also a better understanding of the concepts of the textbooks and, thus, after the revisions are made, Viel Spaß mit Deutsch will be the most appropriate textbook for preparing high school students in Thailand for future education and careers. ${ }^{60}$

\section{Question 2: What factors should be taken into account in teaching foreign languages?}

According to the statistics of foreign tourists in Thailand in 2004, Germans totaled 455, 170, Austrians 59,797, and Swiss 120,166. ${ }^{61}$ German is the mother tongue and formal language in these countries. Based on the proportion of German speaking tourists from Switzerland, the total number of Germanspeaking tourists was more than 590,000. This means that German is the language spoken by one fifth of all European tourists to Thailand. Thus, German for tourism

\footnotetext{
${ }^{60}$ For example, making use of learners' English knowledge (Saengaramruang 2003 (2); Kusolrod 2003 (2)). See also other studies: Saengaramruang 1992, 1997, 2002 (1), 2003, 2005; Sriuranpong 1997, 2002; Mahakusol 1999; Plabpleung 1999; Boonchim 1999, 2002; Tienboonlertrat/ Charnbanditnan 1999; Ralugmool/Solgosoom 2000; Chunnasart/Sukruen 2000; Kanittapongrat 2001; Woraurai 2003; Thienboonlertrat 2002; Maleehom 2002; Kaewwipat 2001; Littmann/ Weerananthanaphan 2002, Ngaosuwan 1978.

${ }^{61} \mathrm{http} / / /$ service.nso.go.th/nso/data23/stat 23/toc 16 /16.1-1.xls
}

should be encouraged in our German teaching programmes.

\section{Question 3: Who are the policymakers for Thailand's foreign- language learning?}

As long as there is no national office for foreign language teaching, the future of German teaching cannot be determined.

Learners at all levels, still have no clear purpose for learning German. Most highschool students learn German just for the entrance examination, while undergraduate and graduate students have no purpose at all. This has happened not only to German language learners but also to other language learners and students all over the world. Moreover, due to the fact that languages are a communicative tool for future careers and knowing one language is not enough, it is necessary that learners must self-learn continually.

Those who graduated with a degree in German work in different organizations. Some have chances to use German, but some do not. For example, they work as teachers, lecturers, secretaries, translators, interpreters, reporters, embassy staff, and staff for German foundations such as the Konrad Adenauer Foundation. To encourage Thai people to lean German, it is suggested that German firms in Thailand give priority to German-speaking graduates, as Japanese firms do.

For German, educational reform has not had a clear direction, which has caused confusion in many respects, for example, curriculum, content, teaching approaches and media, objectives in producing teachers, and German 
for the entrance examination. To make these points clear, there must be a state policy with clear objectives and plans.

As regards the schools, institutes, and universities which offer German, great dedication and devotion can be seen from teachers and lecturers as well as various types of support from different organizations. But what about the policymakers? Who are the policymakers for foreign language teaching? Who are the policymakers for German language teaching? When is the most appropriate time to start learning a second or third foreign language so that it is not for nothing? ${ }^{62}$ Clearly, there are many questions still to be answered!

\section{References}

Boonchim, Maneerat: "Bildverwendung im Deutschunterricht mit dem regionalen Lehrwerk Viel Spaß mit Deutsch. In: 1. Thailändisches Germanistentreffen. TDLV-Forum 7/2002: 129-144.

Boonchim, Maneerat: "Untersuchung über Deutschlehrer an den Oberschulen in Thailand". In: TDLV-Forum 4/1999: 70-85.

\footnotetext{
${ }^{62}$ According to a survey in 2003, conducted among grade 10 and 12 students in five schools, most of them have learnt English since grades 1, 3, and 5 (some of them from the kindergarten level). Thus, before Thai students start learning German as a second language, they have learnt English for 12 years (Saengaramruang, 2003: 169-71). Other languages which they have learnt are Japanese, Chinese, Spanish, and French. Though the number was slight, it showed that students were more active in learning a third or fourth foreign language.
}

Chunnasart, Paveena / Sukruen, Porntip: "Untersuchung der Meinung von Deutschlehrern über das regionale Lehrbuch Lesen macht Spaß". In: TDLV-Forum 5/2000: 67-77.

Festschrift zum 10. Jahrestage der Wiedereröffnung der Deutschkurse an der Chulalongkorn-Universität zu Bangkok am 12. September 1967. Herausgegeben von den Dozenten des Germanistischen Seminars mit finanzieller Unterstützung der Botschaft der Bundesrepublik Deutschland. Bangkok, 1967.

Kusolrod, Prapawadee: Zur Entwicklung eines Fernstudienangebots "Deutsch als Fremdsprache" für Studienanfänger an der Ramkhamhaeng Universität Bangkok. Dissertation, Universität Kassel, 2003. (1)

Kusolrod, Prapawadee: "Anglizismen und Gallizismen in der deutschen Sprache:

Konsequenzen für den Deutschunterricht in Thailand." In: TDLV-Forum 8/2003: 42-49. (2)

Littmann, Michael / Weerananthanaphan, Kriengtape: "Thesen zur Entwicklung des Faches Deutsch an thailändischen Hochschulen - Analyse der aktuellen Situation und Konsequenzen für eine Veränderung der Curricula". In: 1 . Thailändisches Germanistentreffen. TDLV-Forum 7/2002: 167-73.

Mahakusol: Rattana: "Wortschatzvermittlung im regionalen Lehrwerk Viel Spaß mit Deutsch". In: TDLV-Forum 4/1999: 39-50. 
Maleehom, Chawan: "Landeskundliches Wissen and en thailändischen Universitäten". In: 1. Thai-ländisches Germanistentreffen. TDLV-Forum 7/2002: 174-94.

Ngaosuwan, Narümon: Hauptschwierigkeiten der thailändischen Studenten beim Erlernen der Zielsprache Deutsch. Bangkok: Chulalongkorn Universität, Philosophischen Fakultät, 1978. (Magisterarbeit)

Neuner, G.: "Grußwort zum 1. Thailändischen Germanistentreffen: Chancen und Perspektiven für Detusch als Fremdsprache und die Germanistik nach der Jahrhundertwende - auch in Thailand". In: 1. Thailändisches Germanistentreffen. TDLV-Forum 7/2002: 45-53.

Neuner, Gerhard: Germanistikstudium an ausländischen Hochschulen zwischen Allgemeinbildung und beruflicher Spezifizierung. Welchen Beitrag können die Bezugsfächer an deutschen Hochschulen zur Reformdiskussion leisten? In: Info DaF 13 (1986) 4: 291-303.

O'charoen, Thanomnuan:

"Germanistikstudium in Thailand: Geschichte-Stand-Ausblick". In: Germanistentreffen DeutschlandIndien-Indonesien-PhilippinenTaiwan-Thailand-Vietnam, 3. 8.10.1999. Bonn: Deutscher Akademischer Austauschdienst (DAAD), 2000: 17-29, 169-82.

O'charoen, Thanomnuan: "Der neue Studiengang für Übersetzen und Dolmetschen". In: 1. Thailändisches Germanistentreffen. TDLVForum 3/1998: 71-75.
Otrakul, Ampha: "Übersetzung deutscher Literatur in Thailand - Eine Bestandsaufnahme und Darstellung spezifisch deutsch-thailändischer Übersetzungsprobleme". In: Germanistentreffen DeutschlandIndien-Indonesien-PhilippinenTaiwan-Thailand-Vietnam, 3. 8.10.1999. Bonn: Deutscher Akadenischer Austauschdienst (DAAD), 2000.

Plabpleung, Supatcha: "Analyse des Deutschland- und Thailandbildes im Lehrwerk Viel Spaß mit Deutsch". In: TDLV-Forum 4/1999: 51-57.

Ralugmool, Wilairat / Solgosoom, Ekbuttree: "Interesse an deutschlandkundlichen Themen von Deutsch-schülern in der zentralen Relion und ihre Meinungen zum Lehrbuch Viel Spaß mit Deutsch (Band I, II und III)". In: TDLV-Forum 5/2000: 59-66.

Saengaramruang, Wanna: Deutsche Grammatik. 3 Bde. Bangkok: Chulalongkorn University Press.

Saengaramruang, Wanna: Curriculare Grundlegung eines

thailandspezifischen

Deutschlehrwerks für den Hochschulbereich. Heidelberg: Julius Groos Verlag, 1992. (Sammlung Groos 47).

Saengaramruang, Wanna: "Aktuelle Entwicklung des Germanistikstudiums in Thailand”. In: Reformdiskussion und curriculare Entwicklung in der Germanistik. Dokumentationen der Internationlen Germanistentagung des DAAD, 24.28. Mai 1995, Kassel. Bonn: Deutscher Akademischer Austauschdienst, 1995. 
Saengaramruang, Wanna:

"Aufgabenstellung in einem thailandspezifischen Deutschlehrwerk im Hochschulbereich." In: Info DaF 1/1997: 51-57. (1)

Saengaramruang, Wanna: "Übersetzung Deutsch - Thai / Thai - Deutsch, keine einfache Aufgabe. Was muß man berücksichtigen?" In: TDLV-Forum 2/1997: 7-14. (2)

Saengaramruang, Wanna: "Abtönungspartikeln als Illokutionsindikatoren: Von der Forschung in die Praxis des Deutschund Übersetzungsunterrichts in Thailand". In: 1. Thailändisches Germanistentreffen. TDLV-Forum 7/2002: 331-56. (1)

Saengaramruang, Wanna: "Bericht von der Leiterin der Deutschen Abteilung zur Eröffnung des 1.

Germanistentreffens." In: 1 . Thailändisches Germanistentreffen. TDLV-Forum 7/2002: 26-27. (2)

Saengaramruang, Wanna: "Die Übersetzung der deutschen Abtönungspartikeln in der Literatur ins Thailändische.” In: Akten des X. Internationalen Germanistenkongresses Wien 2000. "Zeitwende - Die Germanistik auf dem Weg vom 20. ins 21.

Jahrhundert", hrsg. von Peter Weisinger, Band 11: Übersetzung und Literaturwissenschaft. Peter Lang 2003: 179-85. (1)
Saengaramruang, Wanna:

"Sprachbewusstheit der thailändischen Deutschlernenden und Vorüberlegungen zu Deutsch als Tertiärsprache in Thailand.” In: Internationales Qualitätsnetz Deutsch als Fremdsprache Tagungsdokumentation 2003: 165 190; also in: $T D L V$-Forum 8/2003: 50-68. (2)

Saengaramruang, Wanna: Thai-Deutsches Wörterbuch für Touristik. 3. Auflage. Bangkok: Chulalongkorn University Press: 2003. (3)

Saengaramruang, Wanna: Essen und Trinken im Wortschatz und in Redewendungen im Deutschen und im Thai. Bangkok: Faculty of Arts, Chulalongkorn University, 2005. (1)

Saengaramruang, Wanna: Thai-Deutsches

Wörterbuch. 2 Bde. Bangkok:

Chulalongkorn University Press: 2005. (2)

Saengaramruang, Wanna: German for daily communication. Bangkok: Chulalongkorn University Press: 2006. (in the production)

Srikeaw, Pussadee: "Die Rolle des Thailändischen Deutschlehrerverbands." In: 1. Thailändisches Germanistentreffen. TDLV-Forum 7/2002: 33.

Sriuranpong, Wilita: Die Objektstellung im Deutschen und im Thai. Eine kontrastive Analyse". In: TDLV-Forum 2/1997: 1523.

Sriuranpong, Wilita: Wortstellung in Deutschen und in Thai. Heidelberg: Julius Groos Verlag, 1997. 
Sriuranpong, Wilita: "Internationalismen im Deutschen und im Thai". In: 1 .

Thailändisches Germanistentreffen. TDLV-Forum 7/2002: 222-38.

Taatloha, Prisna u.a.: Viel Spaß mit Deutsch. Ein Lehrwerk für Jugendliche in Thailand. Bd. 1-3. 2. Auflage. Bangkok: Duang Kamol, 1994.

Taatloha, Prisna: "Entwicklung des Deutschunterrichts an der Oberschule in Thailand." In: 1. Thailändisches Germanistentreffen. Tagungsbeiträge. TDLV-Forum 7-2002: 195-204. [in Thai]

Tamura, Phanda / Palanuwech, Rudee: Deutsch für Anfänger I, Deutschunterricht für Thailänder. Lehrbuch. (in the production).

Thienboonlertratana, Walee: "Studie über den Artikelgebrauch der Studenten". In: 1. Thailändisches Germanistentreffen. TDLV-Forum 7/2002: 129-44.

Tienboonlertrat, Walee / Charnbanditnan, Pornsawat: "Erwartung und Einstellung der Deutschlerner auf dem Gymnasium vom Deutschunterricht". In: $T D L V$-Forum 4/1999: 58-69.

Weerananthanaphan, Kriengtape: "Das Curriculum Deutsch an der Khon Kaen Universität, Thailand". In: Germanistentreffen DeutschlandIndien-Indonesien-PhilippinenTaiwan-Thailand-Vietnam, 3.8.10.1999. Bonn: Deutscher Akademischer Austauschdienst (DAAD), 2000: 309-315.

Woraurai, Sornpram: "Die Relativsätze im Deutschen und im Thai". In: $T D L V$ Forum 8/2003: 76-87.

\section{From Internet}

http://www.auswaertigesamt.de/www/de/ind ex html

http://www.deutscher-sprachrat.de

http://www.nso.go.th/thai/stat/dw44/toc $16 . h$

$\underline{\mathrm{tm}}$ 